an extremely flat country, though all $4,000 \mathrm{ft}$. above the level of the sea. When first discovered I was without paper, but borrowed a little from an Arab, and sent a short account home. I had so much trouble from attendants that I took only the barest necessaries. Yet no sooner was the discovery announced at the coast than the official description was forthwith sent to the Bombay Government, that 'the lake is like Nyassa, Tanganyika, and the Albert Nyanza, overhung by high mountain slopes, which slope down to great plains, which, during the rainy season, become flooded, so that caravans march for days through water knee-deep seeking for higher ground on which to pass the night.'

"The only mountain slopes are ant-hills, some of them 2oft. high. They could scarcely be called high unless thought of as being built on the top of the 4,000 ft. These statements are equally opposed to the truth, as the Cazembe town is built on the banks of the Luapula.

"People having a crochet for map-making traced every step of the Portuguese slaving expeditions to Cazembe, and built the village in latitude $8^{\circ} 43^{\prime}$ South-that is, in deep water, near the north end of Lake Moero, and over 50 miles from Luapula. I found it in latitude $9^{\circ} 37^{\prime}$ South, and on the banks of a lagoon or loch, having no connection with Luapula, which river, however, falls six or seven miles west of the village of Moero.

"Now it is very unpleasant for me to expose any of these misstatements and so appear contradictious. But what am I to do? I was consulted by Sir Roderick Murchison as to this present expedition, and recommended the writer of the above as a leader. Sir Roderick afterwards told me that the offer was declined unless a good salary and a good position to fall back upon were added, as Speke and Grant had, on their pay and commission. He then urged the leadership on myself as soon as the work on which I was engaged should be published. My good, kind-hearted friend added, in a sort of pathetic strain, 'You will be the real discoverer of the source of the Nile.' I don't wish to boast of my good deeds, but I need not forget them. . .."

\section{SOUNDINGS IN THE PACIFIC}

$\mathrm{R}$ ECENT explorations in the Pacific Ocean indicate $R$ that its bed is singularly level. The soundings of the U.S. steamer Tuscarora, Capt. George T. Belknap, between Cape Flattery and Oonalaska, were described in NATURE, vol. viii. p. I50. Upon the conclusion of that cruise, which included also soundings from Cape Flattery to San Francisco, a month was spent in the latter harbour, and on December 5 a survey was begun between that port and San Diego on the same coast, especially between depths of 100 and 1,500 fathoms. The latter depth or a greater one is reached precipitately along the entire coast of California, at distances of 20 to 70 miles from shore. Off the Golden Gate, in the latitude of San Francisco Bay, at a distance of 30 miles, there is 100 fathoms ; at 55 miles' distance, there is a sudden descent from 400 fathoms to a depth of two miles; at 100 miles out, 2,548 fathoms failed to reach bottom.

Soundings between San Diego, California, and Honolulu, Sandwich Islands, show that this part of the Pacific is a basin with precipitous sides and a comparatively level bottom. The distance between these points, surveyed by the Tiscarora, is 2,240 miles. The work was accomplished between January 6 and February 3, favourable weather being experienced during almost the entire voyage.

In the first 100 miles west from San Diego, there appear to be two valleys and two peaks. The first valley is from 622 to 784 fathoms depth ; the first peak 445 fathoms, the second valley 955 fathoms, the second peak 566 fathoms. Thence a precipitous fall takes place, giving in lat. $31^{\circ} 43^{\prime} \mathrm{N}$, long. $119^{\circ} 28^{\prime} \mathrm{W}$., at 115 miles from
San Diego, a depth of 1,915 fathoms. After that there is a gentle slope with comparatively unimportant interruptions, at the rate of three feet to the mile, to the point of greatest depth, 3,054 fathoms, at a distance of about 400 miles east of Honolulu. The sharpest elevation is a rise about midway between the United States and the Sandwich Islands, in lat. $26^{\circ} 30^{\prime} \mathrm{N}$., long. $127^{\circ} 37^{\prime} \mathrm{W}$., the highest portion of which is 2,159 fathoms below the surface. At the next cast of the lead, the valley to the west of this elevation took 2,650 fathoms. The fall of the side of the basin east of Honolulu is even more remarkable than the descent off the American coast. Fifty miles from Honolulu, soundings gave 498 fathoms; at 40 miles farther east, in lat. $21^{\circ} 43^{\prime}$. N., long. $156^{\circ} 2 \mathrm{r}^{\prime}$ W., the depth was 3,023 fathoms. Between the last-mentioned point and that of greatest depth a hill rises, on whose summit there are only 2,488 fathoms of water.

These soundings coincide very nearly with the determinations of the depth of the Pacific made on theoretical grounds by the United States Coast Survey in 1854 . Those calculations were based on the movements of tidal waves occasioned by earthquakes in Asia. The wave that reached San Francisco had a length of 2 ro to $2 r y$ miles, an oscillation of 35 minutes, and a velocity of 6.0 to 6.2 miles per minute. This would give a depth of 2,200 to 2,500 fathoms. Similar data with regard to the wave that reached San Diego (having a length of 186 to 192 miles) were calculated as giving an average depth of 2 , 100 fathoms. The average depth of the present soundings is about 2,400 fathoms.

The bottom is generally a soft, yellowish-brown ooze, better suited in this respect, as well as in being more level, than the route surveyed toward Oonalaska, for a telegraphic cable. Other considerations of an economic character, such as prospects of connection with other telegraph lines, may also serve to overbalance the shoriness of the more northern route, and there is much better prospect of fair weather for laying a cable and keeping it in repair in the lower latitudes.

Surface-temperatures rose from $59^{\circ} \mathrm{F}$. near San Diego, to $74^{\circ} \mathrm{F}$. near Honolulu; temperatures at ro5 fathoms between the same places rose from $50^{\circ} \mathrm{F}$. to $63^{\circ} \mathrm{F}$. These, of course, indicate the equatorial current. At 300 fathoms the temperature was constant at $43^{\circ} \mathrm{F}$. At bottom, the temperature was everywhere $35^{\circ} \mathrm{F}$., except in a single instance where it was $x^{\circ}$ colder. The uniformity of temperature below I, 600 fathoms was noticeable.

One wire has been used in all these soundings, which were made every 40 miles, and the apparatus still works excellently.

\section{CHARLES SAINTE-CLAIRE DEVILLE'S} WEATHER PROGNOSTICATIONS

THE prognostications delivered by M. Charles SainteClaire Deville, in his communication of March 2 before the French Institute, were wonderfully fulfilled, at least for Paris, the cold period having had its beginning on the 9 th, and its end on the 13 th, as was predicted. Public attention was all the more attracted because the cold was manifested by a heavy fall of snow, which was the first of the year. Having recently visited M. Ch. SainteClaire Deville, the learned physicist was kind enough to explain everything connected with his theories.

M. Ch. Sainte-Claire Deville has very often published similar prognostications which were always successful, but never in so striking a way. He has been a constant compiler of meteorological records for nearly twenty years; and being the Inspector-General of the French Meteorological Stations, as well as a member of the French Academy of Sciences, he has consequently at his command an immense number of trustworthy observations.

He has discovered that there is monthly a large thermometrical oscillation, which he calls dodecuple, from the 